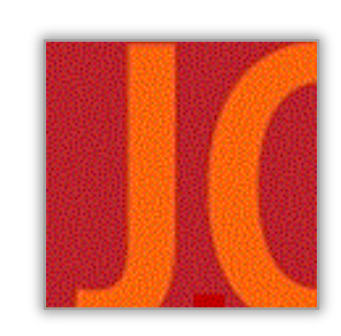

\title{
Walking the Talk: Three Language Educators Engage in a Walking- Based Art Inquiry for Anti-Racist Education
}

\author{
Adriana Oniță, University of Alberta \\ Lébassé Guéladé-Yaï, University of Alberta \\ \& Lucie Wallace, Independent Scholar
}

\begin{abstract}
:
As language and art educators committed to anti-oppression, we sought to explore how walking and art-making help us reflect, inquire, create and act upon new understandings of antiracist education. Living in three different cities (Edmonton, Vancouver and Palermo), we collaborated on a walking-based art inquiry for ten weeks in the summer of 2020, combining walking, art-making (photography, painting, mixed-media collage, screenprinting and poetry), reflecting and discussing. We were curious to investigate, both individually and collaboratively, what an anti-racist curriculum looks and feels like to us, and what walking and art-making might do in the process of learning and teaching. We situated our project in an arts-based research paradigm (Conrad \& Beck, 2015), and we were inspired by Feinberg's (2016) walking-based pedagogy and Judson's (2018) walking curriculum. This article presents artistic experiments we created, as well as curricular insights that emerged from our process, for example, that walking and art may serve as dehabituating forces to help us openly feel, question, protest, and reimagine education, from intersecting perspectives of race and language.
\end{abstract}

Keywords: arts-based research; anti-racism; language education; walking curriculum 


\section{Exploration d'une pédagogie basée sur la marche et les arts vers un curriculum antiraciste}

\section{Résumé :}

En tant que pédagogues en langues et en art, nous sommes toutes les trois engagées dans la lutte contre l'oppression. C'est au travers de la marche que nous avons cherché à explorer comment celle-ci combinée à la création artistique contribue à la réflexion, au questionnement et au développement créatif dans le but de développer une riche compréhension de ce qu'est l'éducation antiraciste. Bien que nous vivions dans trois villes différentes (Edmonton, Vancouver, Palermo), nous avons pu collaborer à une enquête artistique basée sur la marche qui a duré dix semaines. L'exploration s'est faite en combinant la marche, la création artistique (photographie, peinture, collage de techniques mixtes, sérigraphie et poésie), la réflexion et la discussion. Nous étions à la recherche de ce à quoi pourrait ressembler un curriculum antiraciste, et le rôle que la marche et l'exploration artistique pourraient avoir dans le processus d'apprentissage et d'enseignement. Nous avons situé notre projet dans un paradigme de recherche basé sur les arts (Conrad et Beck, 2015), et nous nous sommes inspirées de la pédagogie de la marche de Feinberg (2016) et du programme de marche de Judson (2018). Cet article présente nos expériences artistiques, ainsi que nos réflexions curriculaires qui ont émergé de notre processus. Par exemple, nous nous sommes rendu compte que la marche et l'art peuvent mener à nous déhabituer pour ainsi nous aider à ressentir autrement, à remettre en question, à protester et à observer l'éducation d'une perspective d'intersectionnalité de langue et de race.

Mots clés : la recherche fondée sur les arts; l'antiracisme; l'enseignement de langues; curriculum de marche 


\section{Our Research Process and Paradigm}

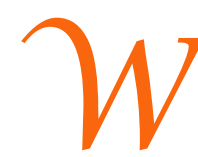
hat do walking, art-making and anti-racism work have in common? In the summer of 2020, midway through une année tumultueuse, the three of us embarked on a ten-week experiment ensemble. As friends, artistes visuelles and art/language educators, we asked: How might walking and art-making help us reflect, inquire, create and act upon new understandings of anti-racist education? Though we live in trei orașe diferite (Edmonton, Vancouver and Palermo), we shared our daily walks, artworks and réflexions, through a group chat, video calls and a collaborative document.

Exploring "walking as a creative process and an artistic form" (Feinberg, 2016, p. 148) for antiracist education invited us to rallentare and use our whole bodies to reflect and create meaning. We surrendered to la physicalité du processus artistique, allowing play and experimentation to challenge our taken-for-granted knowledge, habits and biases, as educators. We knew from our time working together as art and language educators at the Art Gallery of Alberta that l'art a le potentiel d'agir comme un "dehabituating force", allowing us "to break with typical ways of thinking through the creation of new bodily sensations" (Beier, 2014, p. 17). Similarly, on a noté que the act of walking also holds ce potentiel. As wew@ndered, affective experiences arose first and language later, allowing us to feel and see familiar places and events differently. As Judson (2018) reflects, "on foot, over time, we can hope to regain some of what we lose as language-using beings" (p. 12), namely feeling and imagination, "words that rarely take center stage in curriculum talk" (p. 23). For us, a walking and arts-based anti-racist curriculum necessarily centers les sensations et les émotions du corps, selfexpression, dehabituation and imagination.

Thus, we situate our project within an arts-based research paradigm, where our own artistic practices, processes, and products, form baza anchetei and directly generate meaning and producerea de cunoștințe. For Conrad and Beck (2015), an arts-based research paradigm is grounded ontologically in the belief that all humans are fundamentally creative and aesthetic beings, and epistemologically in the acknowledgement that there are multiple ways of coming to know through creating, embodiment, sensations, affect, intuition and spirit. Axiologically, an arts-based research paradigm according to Conrad and Beck (2015) values the ethics of honouring relaţii (both human and more-than-human), collective meaning-making, and anti-oppression. En plus, methodologically, arts-based research is unique in the primacy that is given to interacting with, and making art. We invite you, drag cititor, to attune equally to our artworks and words, to embrace l'ambiguité and disconfortul potenţia/ that often accompanies being a language learner or art viewer, and to explore both the "theoretical potential and the transformative potential" of art in and as research (Knowles \& Cole, 2008, p. 67) for anti-racist education. We invite you to read and listen to our languages cu un suflet deschis. In this paper, you will witness our languages appear in italics. As Nigerian author Jumoke Verissimo (2019) posits, when italics are used in multilingual writing, they can act as an "assertion of selfhood" (para. 6) that accomplish several things at once: they can "shift the gaze and 
force attention to lingual hybridity as a state of existence" (para. 19); "highlight the incompetence of English to assimilate" (para. 19); and "invite the reader to pause and reflect on the fact that they have stumbled on another world with all its flourishes" (para. 7). In short: "the italics as emphasis ask—do you want to listen?" (para. 21).

\section{Lébassé: Flipping the Frame, Repurposing Blackness}

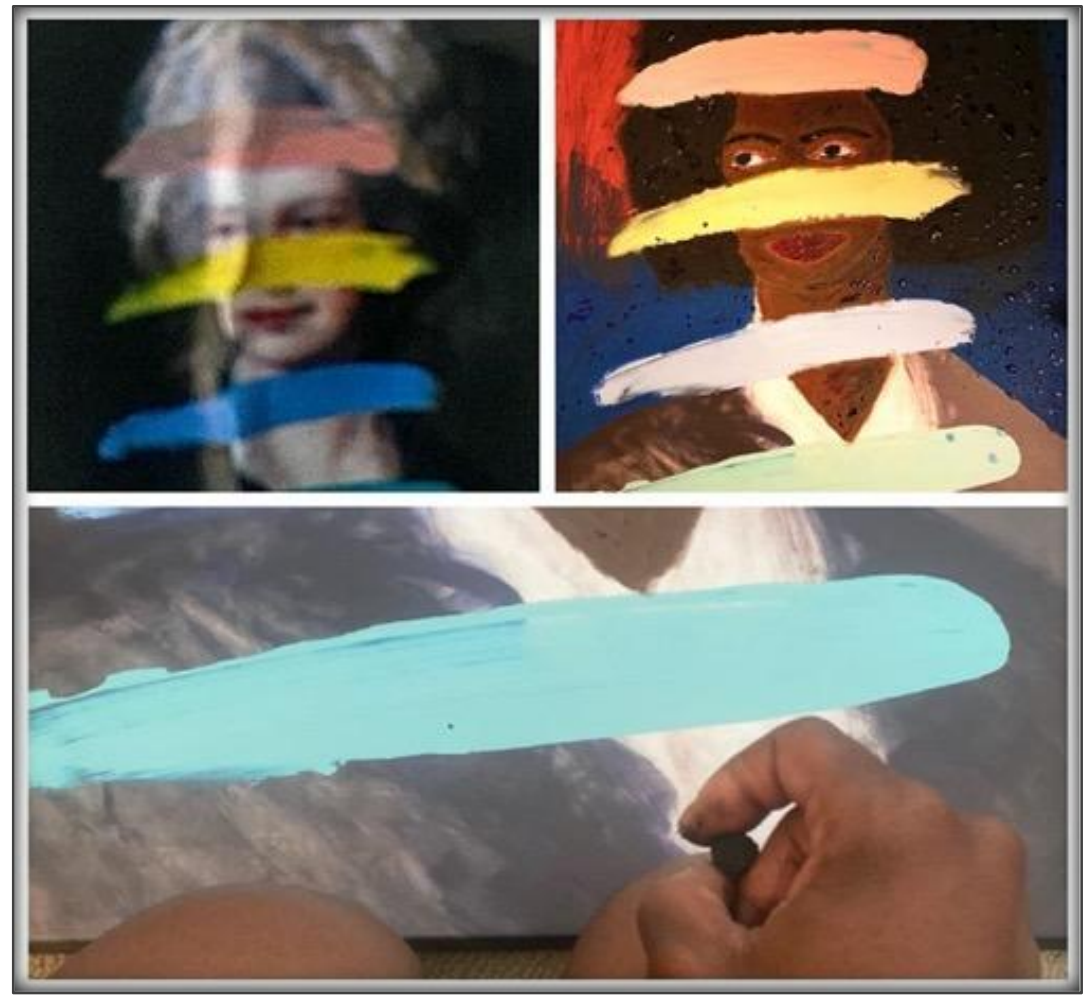

Repurposing Blackness Portrait 1. Lébassé Guéladé-Yaï, July 2020. Oil pastel and watercolour on IKEA Print by Chad Wys, engaged with permission of the artist. Photos taken with iphone by author.

I am a second generation Black Canadian; my parents were born in Côte d'Ivoire and migrated to Canada in the early 80 's to pursue their post-secondary education. My experience with racism is one that is rooted in my childhood, especially my experience in primary school in Québec. My parents' experience with racism s'est concrétisée pour eux in their early twenties when they left Africa. Our understanding of injustice and racism is complex and exists sous forme de conflit interne due to the colonial context from which emerges our French identity. Le travail de décolonisation de nos esprits continues in a quest for freedom and reconnection to our roots away from the land of our ancestors. With this in mind, exhausted from how June 2020 had started, pour ajouter au mal déjà présent d'une pandémie qui nous présentait depuis janvier d'insurmontables vérités, I logged off from another working-from-home week to join the biggest Black Lives Matter protest in Alberta. Nous étions 15,000 Edmontonians, masqués, physically distanced, tous unis in response to the death of George Floyd at the hand of officer Derek Chauvin. 
When June 2020 happened, all over the world, walking evolved to marching. It became harder to distance ourselves du désiquilibre sociale. Et c'est dans ce climat, that I walked, protested and reflected. I thought about the opportunities my parents benefited from, the result of the fight of distant descendants of our ancestors. I was grateful to join this radical movement aware que la boucle ne se ferme pas mais qu'elle s'enchaîne avec moi.

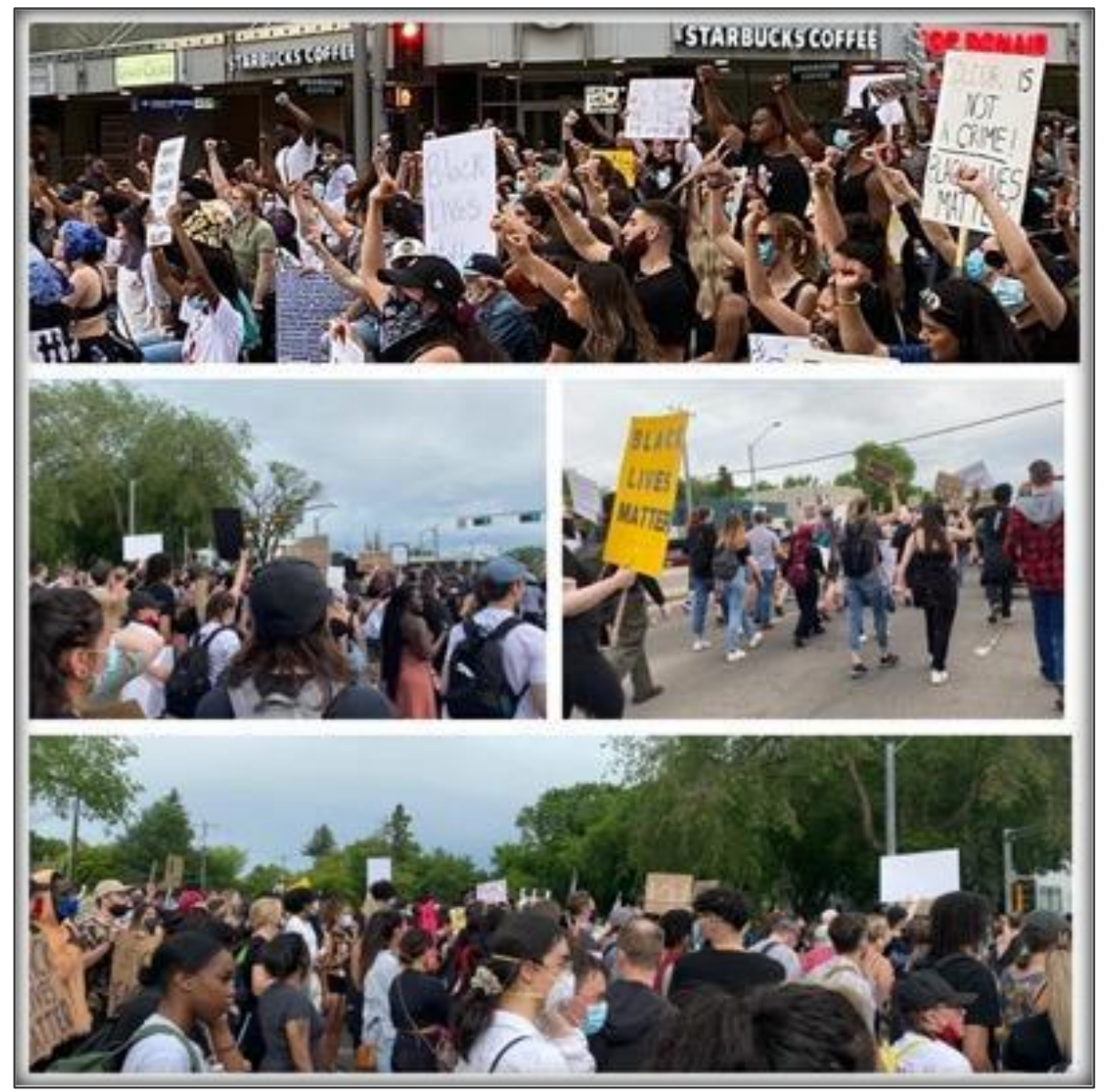

Black Lives Matter Rally 1, amiskwacîwâskahikan/Edmonton. Lébassé Guéladé-Yaï, June 5, 2020. Photos taken with iphone by author. 


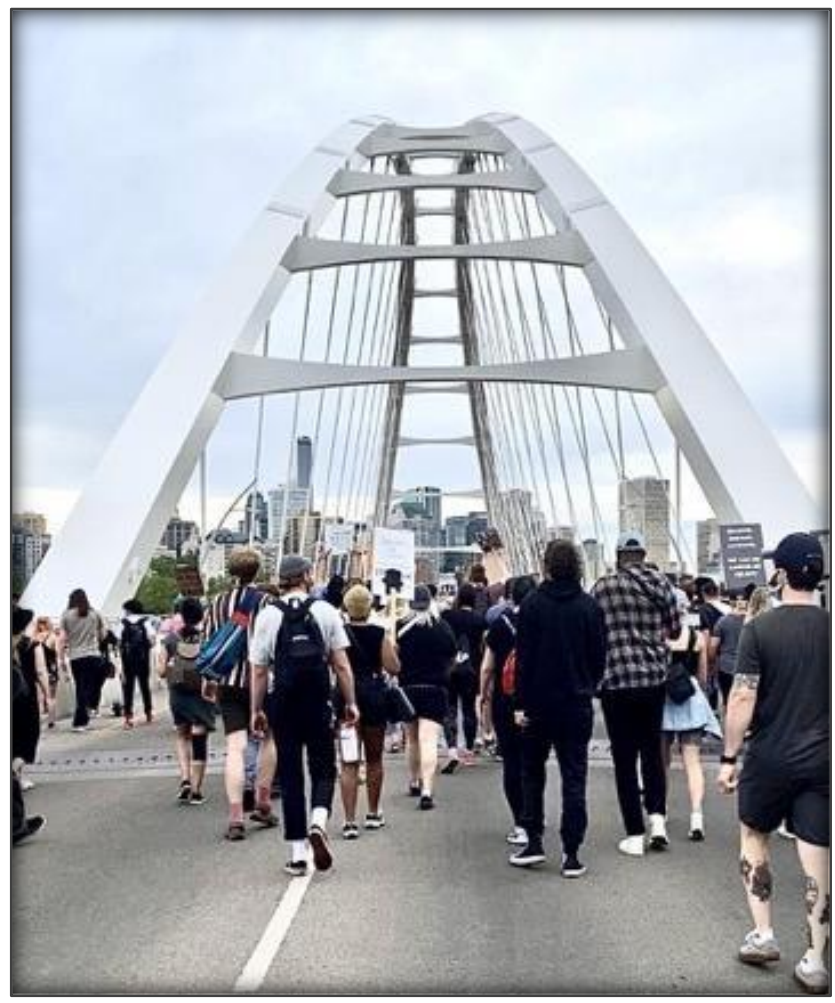

Black Lives Matter Rally 2, amiskwacîwâskahikan/Edmonton. Lébassé Guéladé-Yaï, June 5, 2020. Photos taken with iphone by author.

Marching for change is collectif, whereas mindful walking for introspection is personal. Walking encourages self-reflection and gives way to the importance of the process which is influenced by our personal experiences. What does it mean to walk outside of the parameter of physical destination but rather towards self-discovery? When engaging students through art, I start by opening up a dialogue on the creation of meaning and its many origins. Tout est interprétation. C'est pourquoi engaging with the process helps me see, as it does not cloud my mind with what the outcome should be, but rather helps me understand the choices I make.

A s an artist, mindful walking helps me visualize the tools, media and art techniques I am curious to explore to translate my thought process. As an educator, c'est mon expérience de jeune élève Noire qui me revient and inspires me to use the language of visual art to explore anti-racist education. For one of my walks, I went to IKEA. In the sale section I came across a print called "Brutalized Gainsborough" by Chad Wys: a classical piece turned contemporary, where the artist reappropriated the original artwork by Thomas Gainsborough and created new meaning by adding three stripes of acrylic paint on the canvas. Language education and art education both créent des situations where we are constantly creating new meaning en infiltrant our personal experiences with new, unknown content. The print brought out a memory of me in Grade 1 or 2 drawing myself White. Revisiter ce souvenir made me very uncomfortable. Did I draw myself White because I was ashamed of being Black? Was it my way of portraying neutrality, normalcy? Did I know I was Black? Did my friends know I was Black? Did my teacher ignore my drawing? Should the teacher have sat down with 
me and asked me why I drew myself White? Art and conversations about race peuvent mener à des espaces incomfortables, but the process of growing in these situations and learning from them adds value, while focusing on a possible outcome can narrow the opportunities for change.
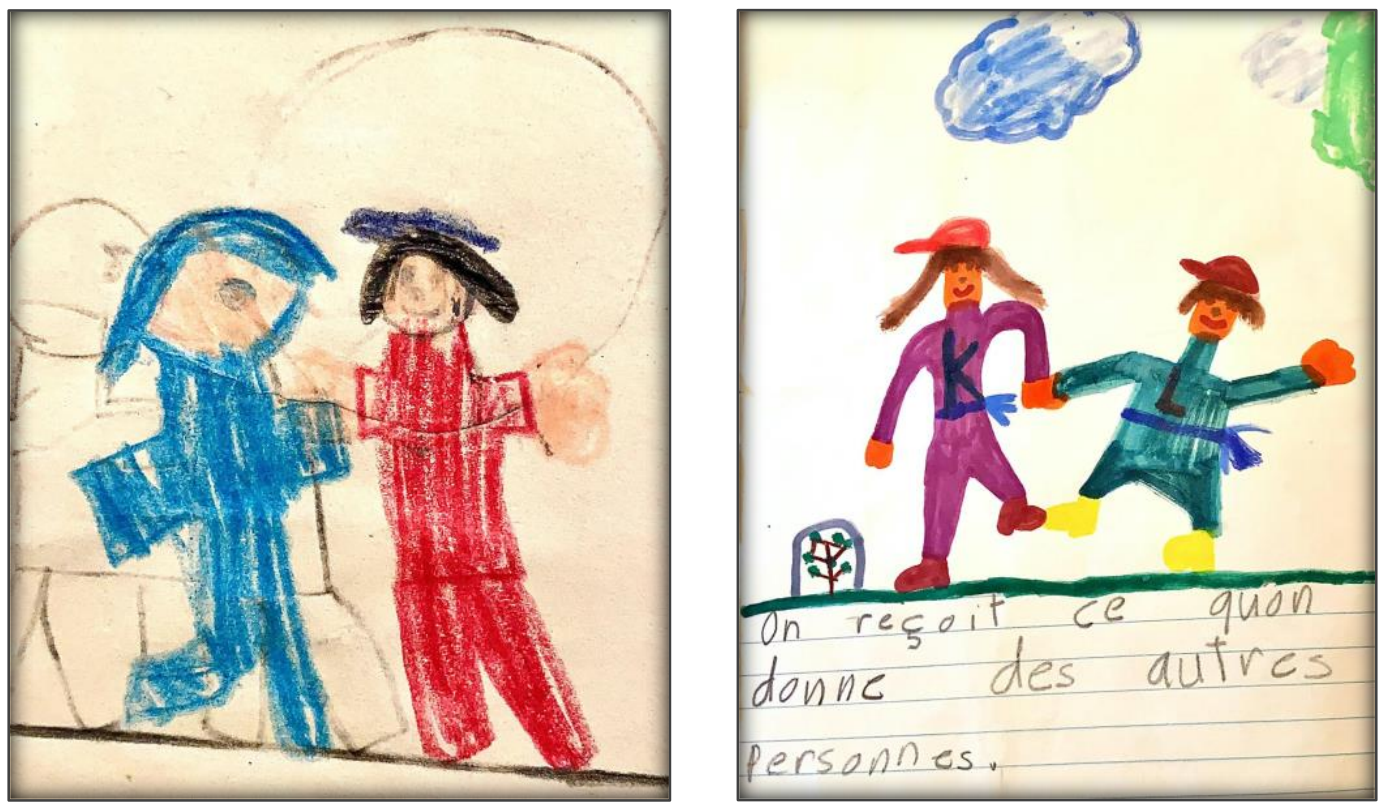

Dessins dans journal d'art [Drawings in Art Journal], Québec. Lébassé Guéladé-Yaï, 1990.

Crayon feutre on manilla paper; drawings by author.

\section{How to Flip the Frame}

1. Get lost et explore your favourite big-box store that sells art. Ikea, Home Sense, or even Walmart will do.

2. Select a mass-produced art print portraying only one racial perspective de l'expérience humaine.

3. Trouve un miroir: look at yourself and see how beautiful you are. What colour are you?

4. Once you've answered the question in Step 3, select the medium of your choice and find the colour that will now become the skin colour. Applique la couleur sur le visage du sujet.

5. Go back to the mirror you used in Step 3. Quelle texture does your hair have? Is your hair short, crépus ou longs? What colour is it? Take notes.

6. Work the canvas, amuse-toi, change the background, add texture.

7. You can work with the features, or add a personal touch to the clothes with real fabric.

8. Congratulations, you have now flipped the frame. The results will differ from one person to another and that's okay, parce que la représentation c'est important. 


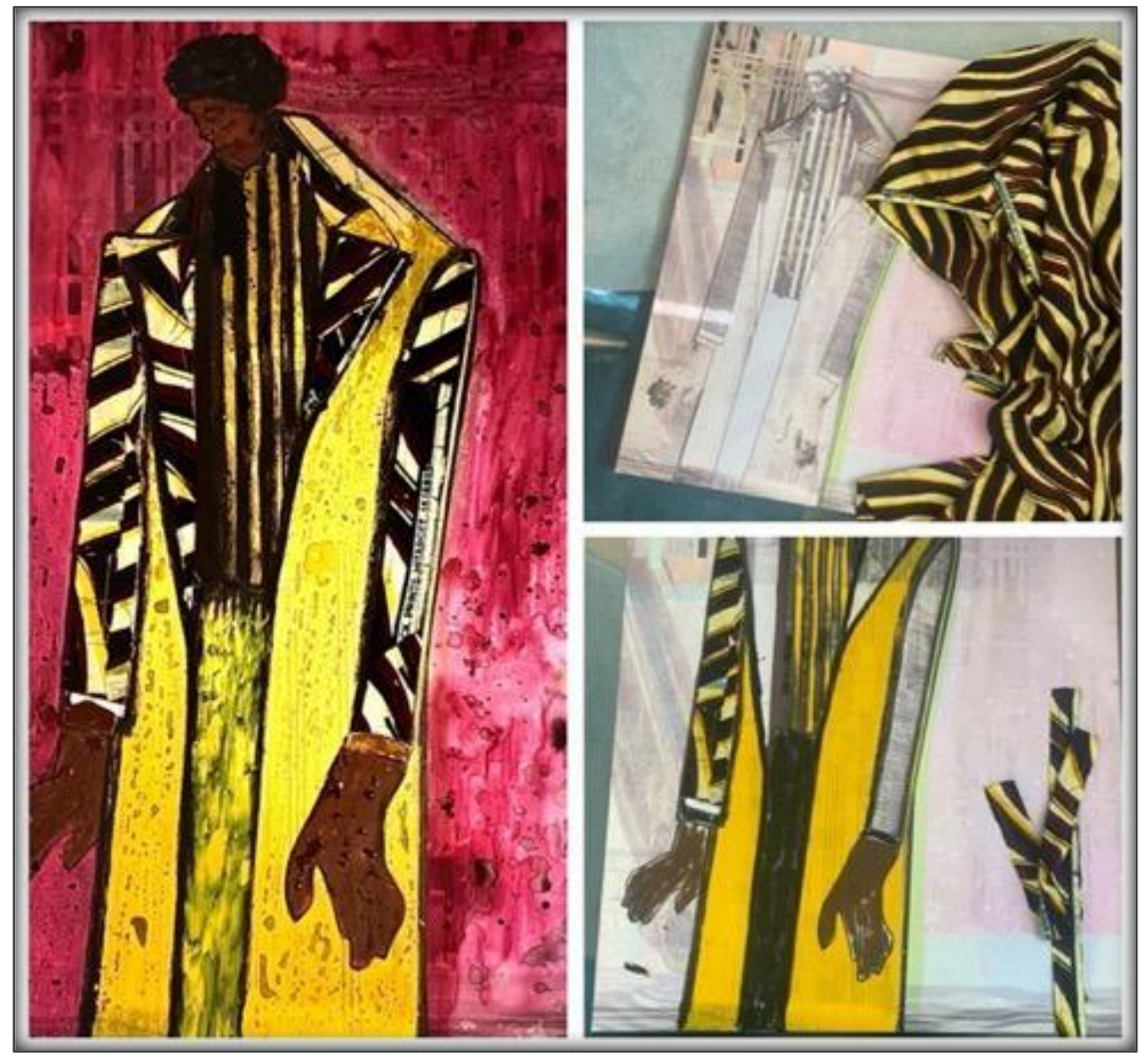

Repurposing Blackness Portrait 2. Lébassé Guéladé-Yaï, July 2020.

Oil pastel and watercolour on IKEA Print ${ }^{1}$; photos by author.

As Dei (1995) reminds us, anti-racist work questions the marginalization of certain voices in society and the delegitimization of their knowledge and experiences in the educational system. Can you belong in an environment where you are not represented? Suis-je qu'objet, si je ne suis pas sujet? Can you find value in art if you don't see yourself in it? The presence of Blackness in artwork used to make me perceive the art as a political piece. However, artwork portraying Whiteness would not make me feel the same, as it was the default representation of lived experiences, la perspective eurocentrique. Selon ma logique, le corps Noir n'était que pour l'art Africain or present to convey the status and power of White people. The same dynamic happened in elementary school where the stories relating to a universal experience shared were mostly those of the White students. Stories en lien with hardship, pain, hunger and violence would always circle back to Africa and the Black experience. J'avais honte de l'Afrique. Too young to understand the microaggressions, I decided to

${ }^{1}$ The images from IKEA in Repurposing Blackness Portrait 2 and Repurposing Blackness Portrait 3 are reproduced in accordance with our interpretation of Fair Dealing for the purpose of research; see Canadian Copyright Act: https://laws-lois.justice.gc.ca/eng/acts/c-42/page-8.html\#h-103269. 
disappear even more. Even though I didn't like my invisible status, I was aware that it was the safest way to exist in the classroom. My experiences were deemed political and were only solicited in a context of difference to compare and contrast with the universal White experience. Anti-racist education is actively choosing to fight any unequal racial relations that exist in the classroom. "Walking the talk" is showing up, no matter how uncomfortable the conversations might be.

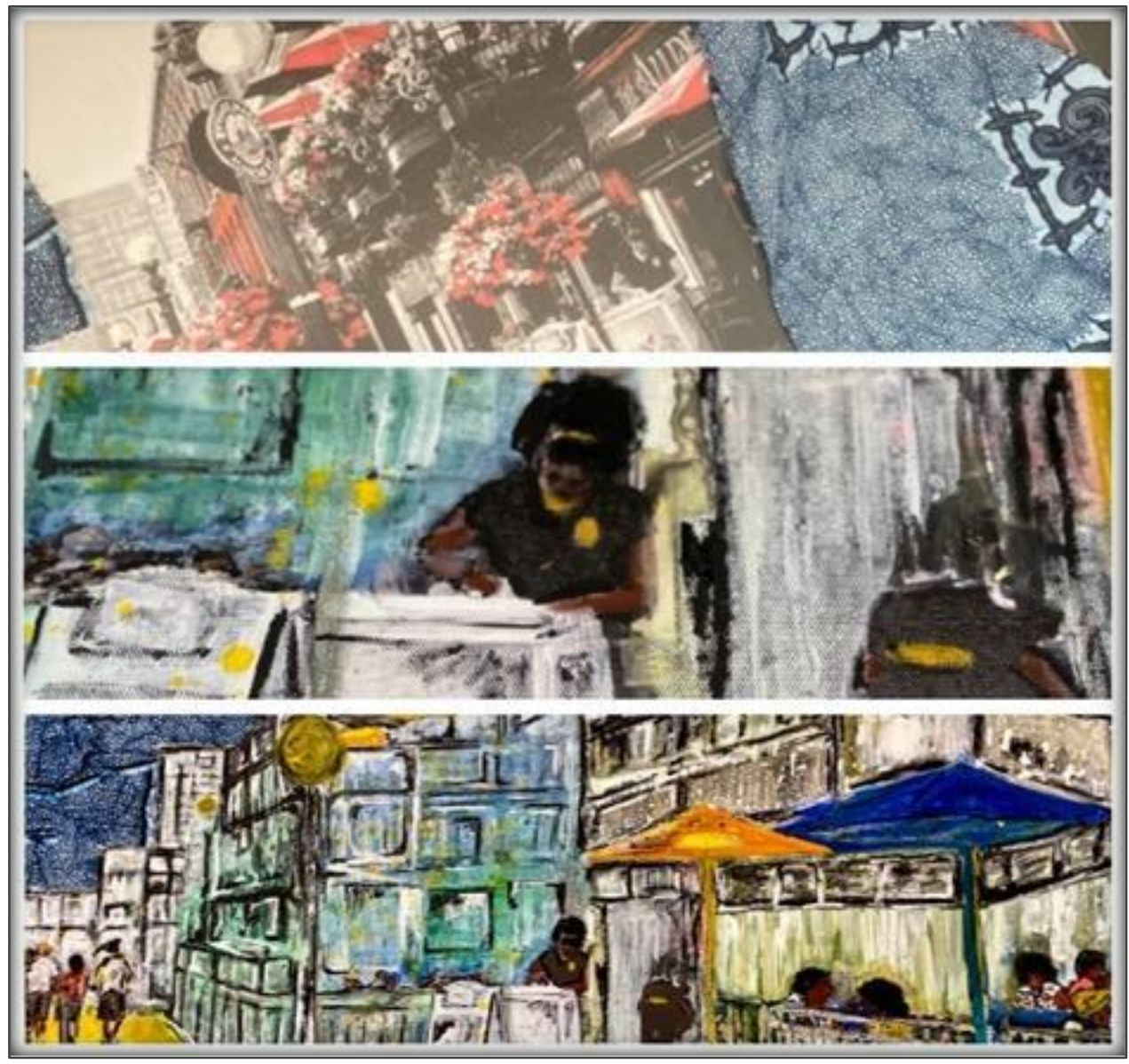

Repurposing Blackness Portrait 3. Lébassé Guéladé-Yaï, July 2020. Oil pastel and watercolour on IKEA print; photos by author. 


\section{Lucie: Réflexions pour le moment présent}
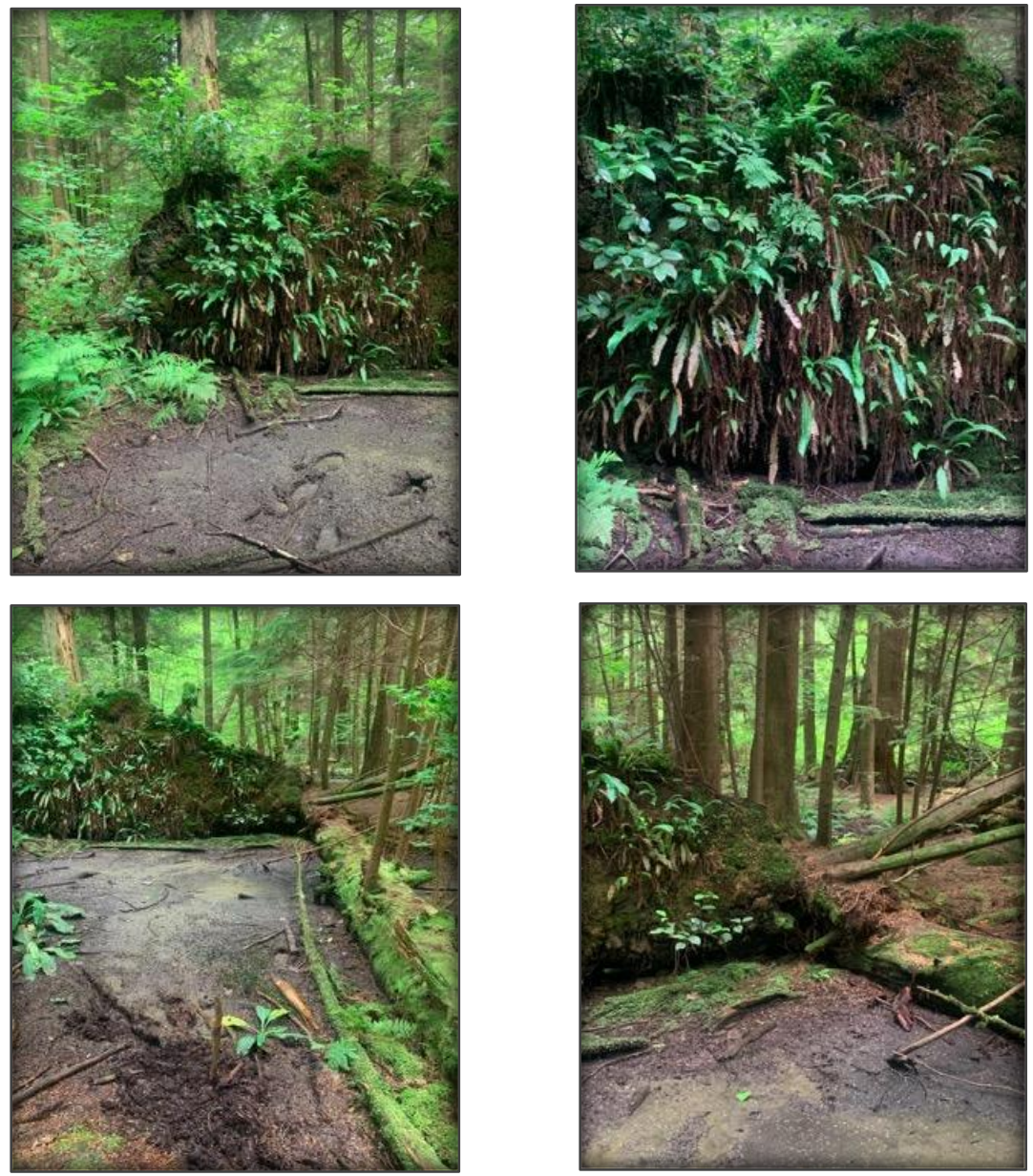

Le Géant Vert [The Green Giant]. Lucie Wallace, July 2020. Series of digital photographs by author.

\section{Into the Forest}

As I walk toward le géant vert, camera in hand, I feel its energy pulling me closer to its core. Stanley Park is situated only ten minutes walking distance from my home in Vancouver. "Cathedral" is the etching marked into the trail post. I instinctively follow the path into the forest. My body seems to ease as it embraces the majesty of the Pacific Northwest forest. Comme un aimant, mon corps est tiré vers le mur de verdure. I turn toward the vines, branches, moss and dew, and choose to follow the wildness of the forest. I distance myself from the park trail and fall deeper into the green. My senses are immersed: I feel the croaking of grandfather trees, the tweeting of colourful birds, the melting of the ground beneath my feet, the strong scent of cedar and the whistling of the wind. 


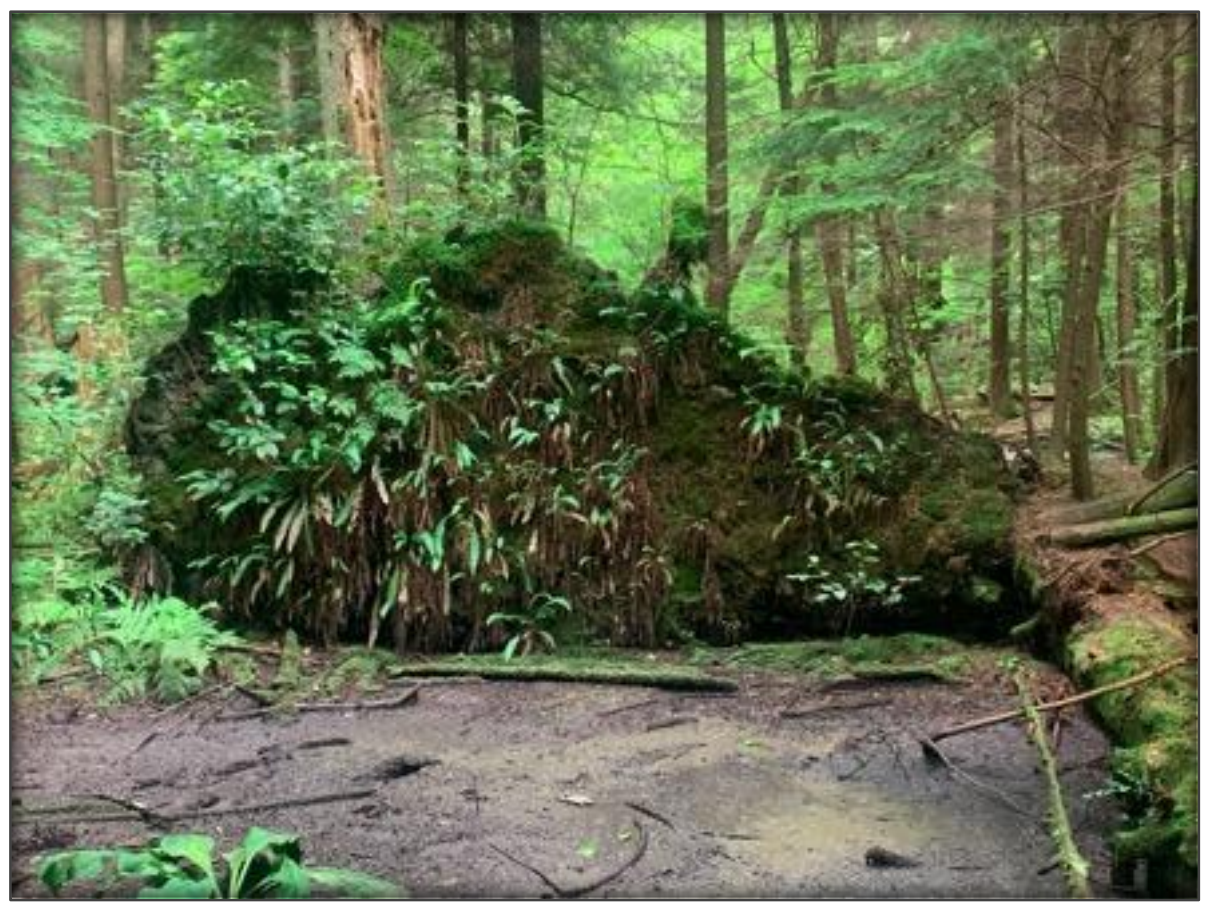

Le mur de verdure [The Green Wall]. Lucie Wallace, July 2020. Photograph by author.

As the forest breathes, I find a fallen tree overgrown by heavy moss, overlapping ferns and new growth. I snap a few photos before I stand immobile. Being still suddenly makes my surroundings feel overwhelming. It is easy to be afraid of living things. Mosquitos swerve around my exposed calves. Crows caw above. The forest surrounds and intimidates. A crack. I look up to meet the gaze of a masked creature with small human-like hands only a few steps away. I hurriedly flee the scene.

I find it slightly disturbing that my mind goes straight to impending doom in a moment of peace in the forest. It seems that, these days, my mind exists in a suspended state of chaos and anxiety. A pandemic, political brouhaha, protests, riots, killings: This is the 2020 mind-a mind where even a beautiful rainforest can feel menacing. Everything around us seems to threaten the life we used to know. I wonder if this sense of anxiety can power opportunities for change. As we teachers get ready to greet our students in sanitized classrooms, we are overwhelmed by the doom of the unpredictable. I must remember that everyone involved in education shares existence in this extraordinary present moment. Perhaps through this moment, I can funnel my concerns into an effort to return to the rudimentary essence of teaching: connection and care.

According to Canadian art educator Adrienne Figliuzzi (2020), precarious times call for a relational pedagogy: "The importance of the educational experience is not the set of outcomes; it is the relations we have in the educational environments and what we learn or gain from those relationships" (para. 5).

In this project, working with my co-authors, I have gained so much: a sense of fulfilment in doing something that matters; a deeper connection with close friends; and a sense that I am cared 
for. This year, at Mulgrave school, in West Vancouver where I teach primary French, I will seek to build meaningful connections with my students in order to design learning engagements that really matter to them. At the beginning of each French class, students will trust that I will listen to them and their learning needs that day. Remembering to teach the whole child, and practicing it, will ensure that the current school year continues to nurture an education of human connection and growth, and consequently, nurtures the anxious mind, heart and soul.

During my walk in Stanley Park, the forest was an intimidating green giant. Like that day, my mind will continue to receive fears with anxiety. However, when it comes to teaching, I will address my current fears with an aim to affect positive long-term change, starting with the care of my students.

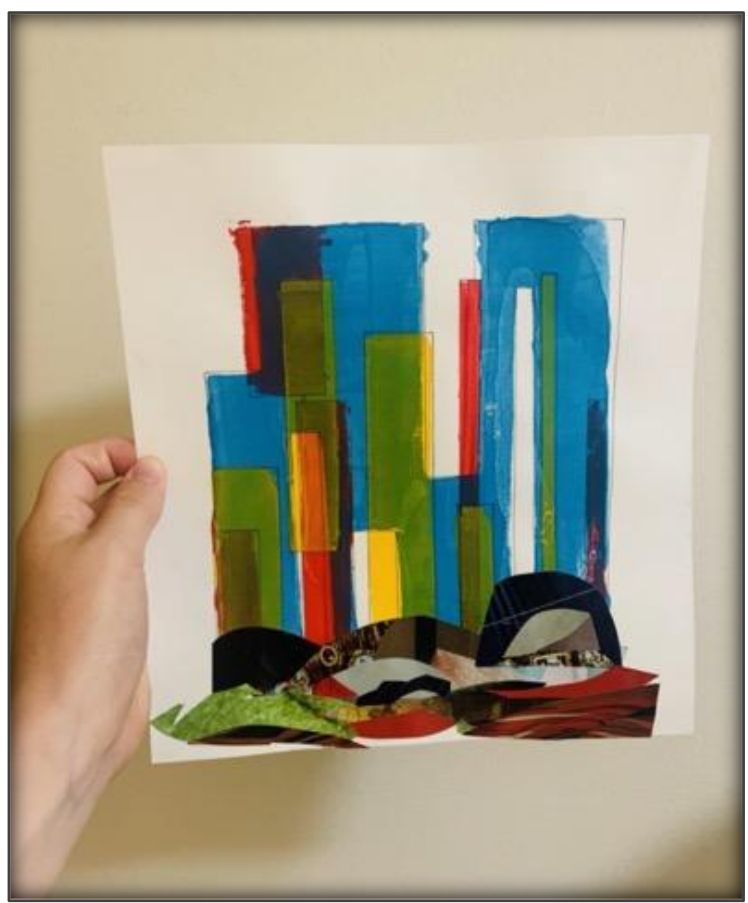

Coexistence : Nous sommes complexes. Nous sommes contradictoires [Co-existence: We Are Complex. We Are Contradictory]. Lucie Wallace, July 2020. Silkscreen, magazine, marker; artwork by author.

\section{Coexistence: Nous sommes complexes. Nous sommes contradictoires.}

Contradictions live within us and the spaces that we create. Marching through the grid-like streets of downtown Vancouver, my feet meet one tall box after another, one perfectly straight road intersecting another. The tall boxes reach and stretch to the horizons avec toutes intentions $d^{\prime}$ imposer et d'intimider. Along the sidewalk, I pass trees whose roots and earth swell within the confines of their designated sidewalk grid. The puffiness resulting from the plants' restricted growth reminds me of the controlling need to correct differences within our stories as a nation, and of what happens when we repress the truth we don't want to see. Flatten, straighten, fit. Yet, underneath and in between the skyscrapers, the unceded land of the Squamish, Coast Salish and Tsleil-Waututh 
people endures. Their stories live here, too. As I try lending an ear to their stories, which have been subject to years of repression, I feel the force of an overriding narrative trying to impose itself yet again. A story that is retold by politicians and education textbook writers. I hear: This is who we are: a country of acceptance, multiculturalism, open mindedness, generosity and freedom! Perhaps it is easier to ignore than admit that hate, violence and discrimination fed systemic racism against Indigenous peoples throughout Canada's history. However, confining, controlling or disregarding this truth does not erase its existence. Giving space to the voices that have been pushed down far too long by the hands of power is every Canadian's responsibility. As a Canadian educator, especially one of a colonial language, I can stock my classroom bookshelf with local Indigenous stories, I can incorporate Indigenous principles of learning in planning and assessing, I can reach out to the Squamish community in West Vancouver, I can introduce Squamish language in the classroom, and I can seek to unlearn colonial ways of teaching language.

Complexities and contradictions exist in our spaces, as well as in the stories we construct about ourselves as a nation. When I come home from my walk, I attempt to replicate, with overlapping rectangular stencils, the geometrics of the urban and of the power structures it represents. Beneath the screenprints lie curvaceous lines, formed from organically shaped magazine cutouts and seek to represent the living land and stories of its people, stories that resist confinement, stories that endure. Together, these distinct realities create my city and my nation.

\section{Linguistic Privilege}

Embarrassingly, in my teens, I could not understand why some immigrants chose assimilation over preservation, celebration and development of their own cultural and linguistic identities. Perched on my high horse of privilege, I felt disappointed when I met families who chose to speak English over speaking their parents' mother tongues. My simplistic conviction that languages were objects for accumulation did not reflect the reality that I was too privileged to experience. The reality was that my mother's mother tongue, le français, held official language status in this country. En tant qu'albertaine francophone dans mon milieu minoritaire, I could be educated, engage inextracurricular activities and take part in a small but thriving community, all in my home language. Still, en grandissant dans une communauté francophone au coeur du Canada Anglophone, I understand the struggle community activists have had to endure in order to provide future generations of Francophone children with the upbringing I received. Although complex, the privilege bestowed upon Francophone and Anglophone speakers in this country as a result of the push for "bilingualism and bi-culturalism" (deux langues, deux cultures, une nation) of the 1960s, ironically means that speakers of heritage languages miss out on those benefits. This has led some parents to tell their children: "Just speak English, this is how you survive in this country-get a job, go to school, make friends, and try to fit in." I now see more clearly this linguistic and cultural privilege given to me over others. Looking back, I would tell my younger self that heritage language learners are subject to "material and symbolic violence at the hands of the dominant societal groups" (Cummins, 2009, p. 45). Such learners often have to "deny their cultural identity and give up their languages as a necessary condition for success in the 'mainstream' society" (Cummins, 2009, p. 45). 


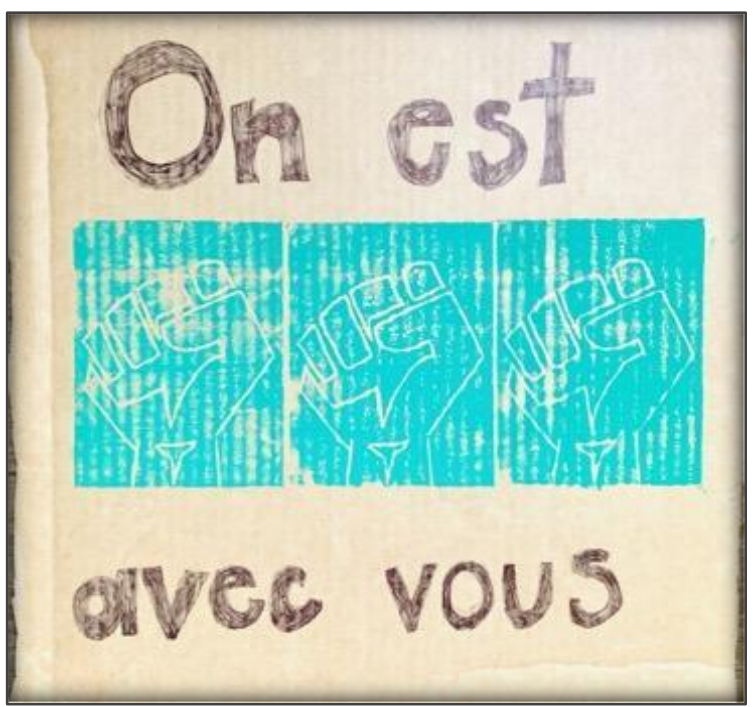

Affiche de manifestation. Lucie Wallace, June 2020. Cardboard, marker, silkscreen print.

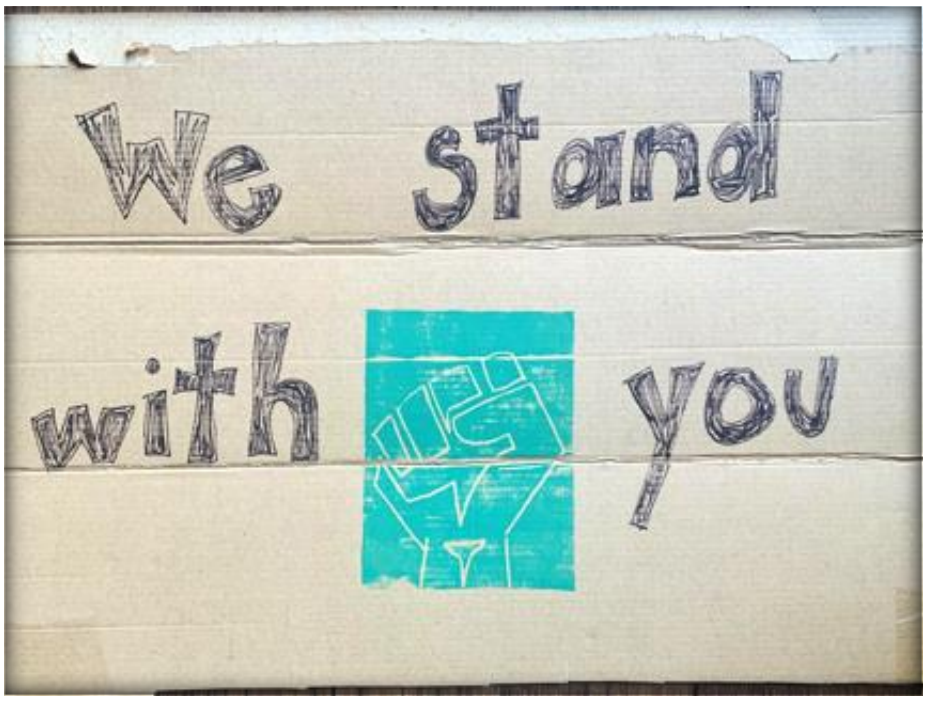

Protest Poster. Lucie Wallace, June 2020. Cardboard, marker, silkscreen print.

As I head back to my language classroom, I wonder how I will translate my new insights for my students. In my ideal classroom, students feel empowered to explore who they are and what they speak. I encourage an inquiry-based, communicative, student-led approach to language exploration, where heritage languages and cultural identities will be powerful tools called upon when making connections to new learnings. Trans-languaging and code-switching are presented as natural ways of expression. I incorporate resources made by people who look like my students, and I encourage exploration of local language communities. As language is not something that can only look or sound one way, we must study varieties of French, including different accents and structures. And rather than focusing on a stereotypical, monocultural French, students explore the cultures of people living in Francophone countries throughout the world, including their different experiences with the language. Finally, I model pride in my home language, not because it occupies a certain linguistic 
and colonial cultural prestige, but because of the way it enriches my life and relationships with others.

\section{Adriana: Walls Teach the Walker}

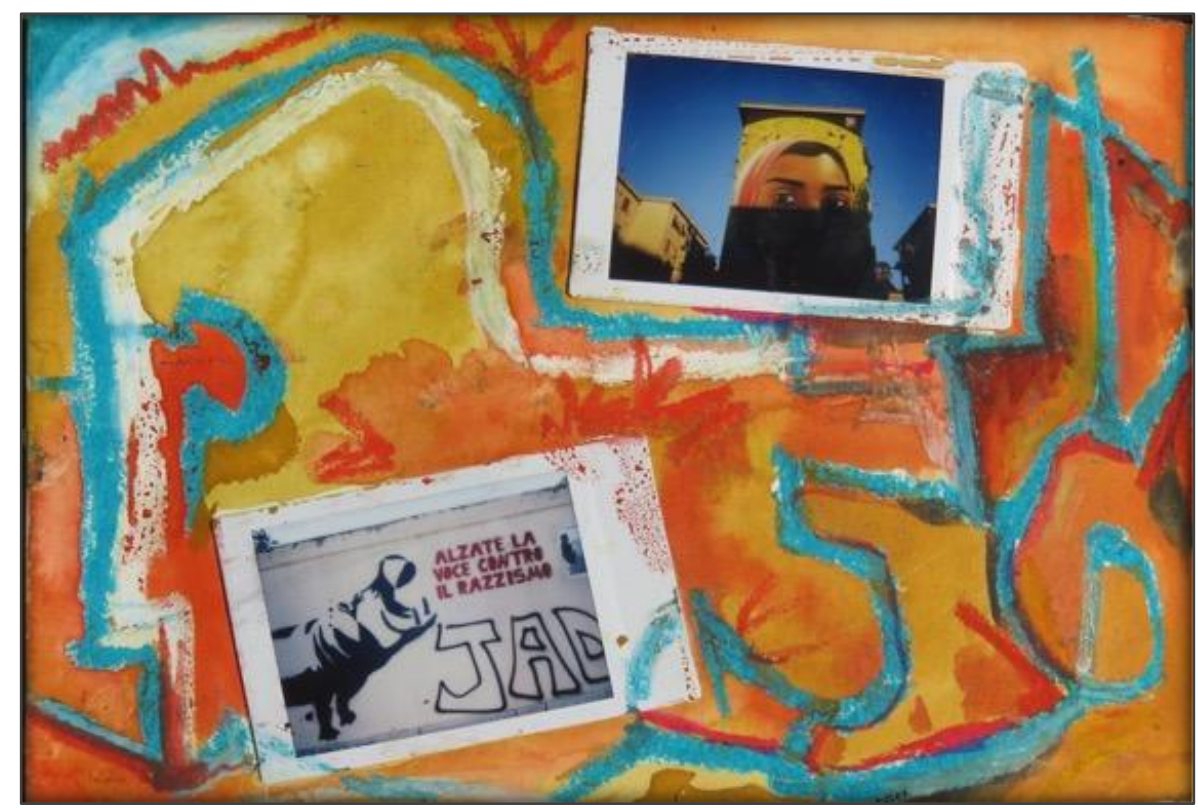

Alzate la voce contro il razzismo 1 [Raise Your Voice Against Racism 1]. Adriana Oniță, 2020. Polaroid, oil pastel and watercolour on paper.

\section{Passeggiate Vietate: Walks Prohibited}

I have taken walking for granted tutta la mia vita. Then, one sudden day in March 2020, when passeggiate were no longer allowed in Italy, I felt perduta. I suddenly lost my way to exercise, relax, reflect, process, plot, breathe and daydream. Though I lived near a beautiful park in Palermo, Villa Bonanno, due to the stringent COVID-19 lockdown in Italy, I, as everyone, was confined to my home for eight weeks. I would often ask my dear friends Lébassé and Lucie, on the phone: what does it mean to teach and research when seated at a computer screen? How can we build and maintain relationships with our students this way? From March to May, I paced the perimeters of my apartment, while talking to them to stay calm and grounded. With their help I was able to creatively emerge from the discomfort and grief of this year, inventing, for my doctoral research, a new digital Spanish Art Camp - an arts-based curriculum for Spanish heritage language learners in Canada-and experimenting with creative ways to teach my post-secondary online curriculum course for future second language teachers in Alberta. 


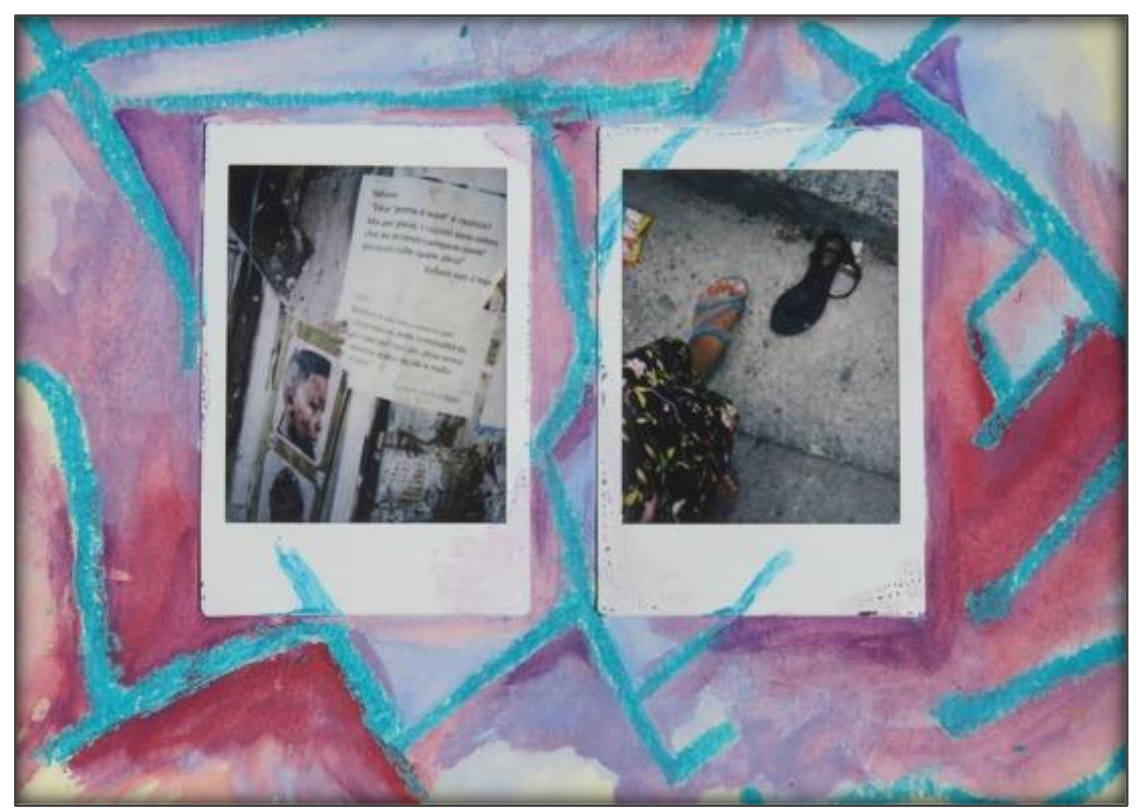

Two Windows Into Walking in Ballarò. Adriana Oniță, 2020. Polaroid, oil pastel and watercolour on paper.

\section{Plimbare}

In May 2020, when I began walking outside again, I felt elated. With mask, sketchbook, paintbrush and camera in hand, am început să mă plimb din nou. First, in my mother tongue -o plimbare este o ceremonie personală. In Romanian, plimbare is somewhere between a stroll and an amble. You hook your hands behind your back, or clasp another's hand. You slow your pace to match your heartbeat. Smell bujori blooms. Gossip, laugh, take the wrong turn. No plan, no purpose, no path to follow. Plimbare is where walking meets fortuity and play.

Though growing up I enjoyed walks in Jilava, Romania, and Edmonton, Canada, in the past year, plimbă rile mele have taken place in Ballarò, a neighbourhood in Palermo, Italy. Walking here includes a soundscape of languages, with Arabic, Bengali, Romanian, Wolof, Sicilian, Yoruba, Italian, Tagalog, and so many others, collaged together. On each plimbare, I take polaroid photographs and write poetry to document what I see and the conversations I have. Later, I glue the polaroids into my sketchbook, draw my walking paths using oil pastels and paint on top with watercolour to represent the mood and questions of the day. Since oil and water do not mix, what emerges is a brightly layered mixed-media experiment of my walking-based art practice (Frimberger, 2016). 


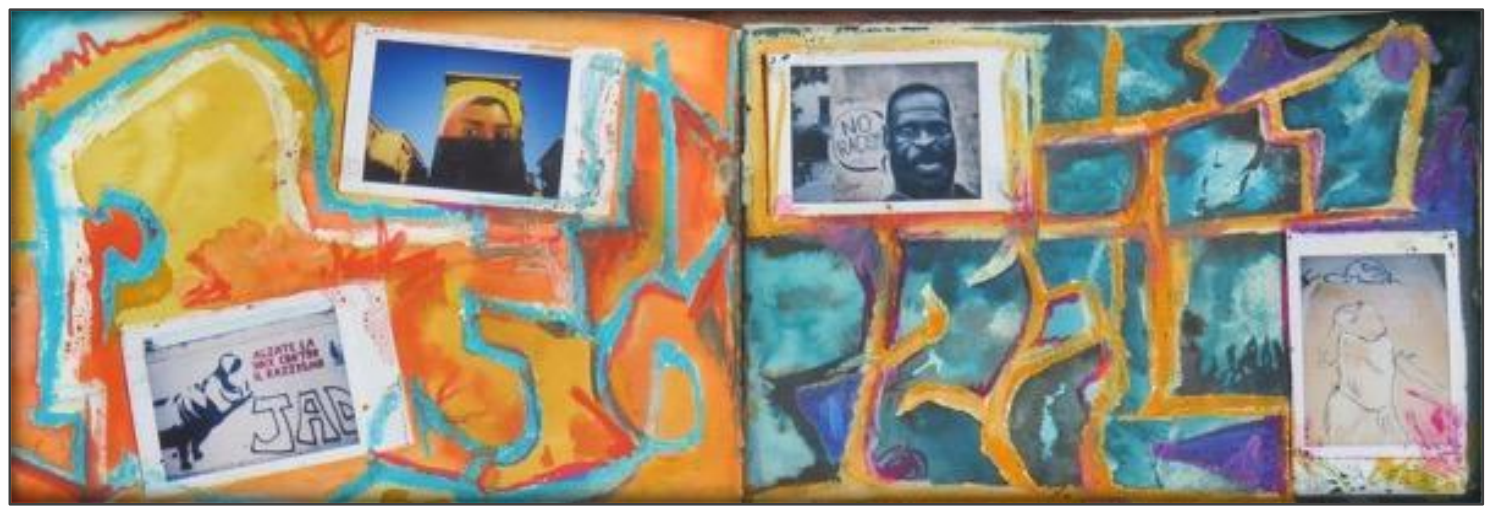

Alzate la voce contro il razzismo 2 [Raise Your Voice Against Racism 2]. Adriana Oniță, 2020. Polaroid, oil pastel and watercolour on paper.

\section{I muri insegnano: The Walls Teach}

In June 2020, as the world continues to cope with three suffocating pandemics-COVID-19, racism and the climate crisis-I noticed the walls of Palermo change overnight.

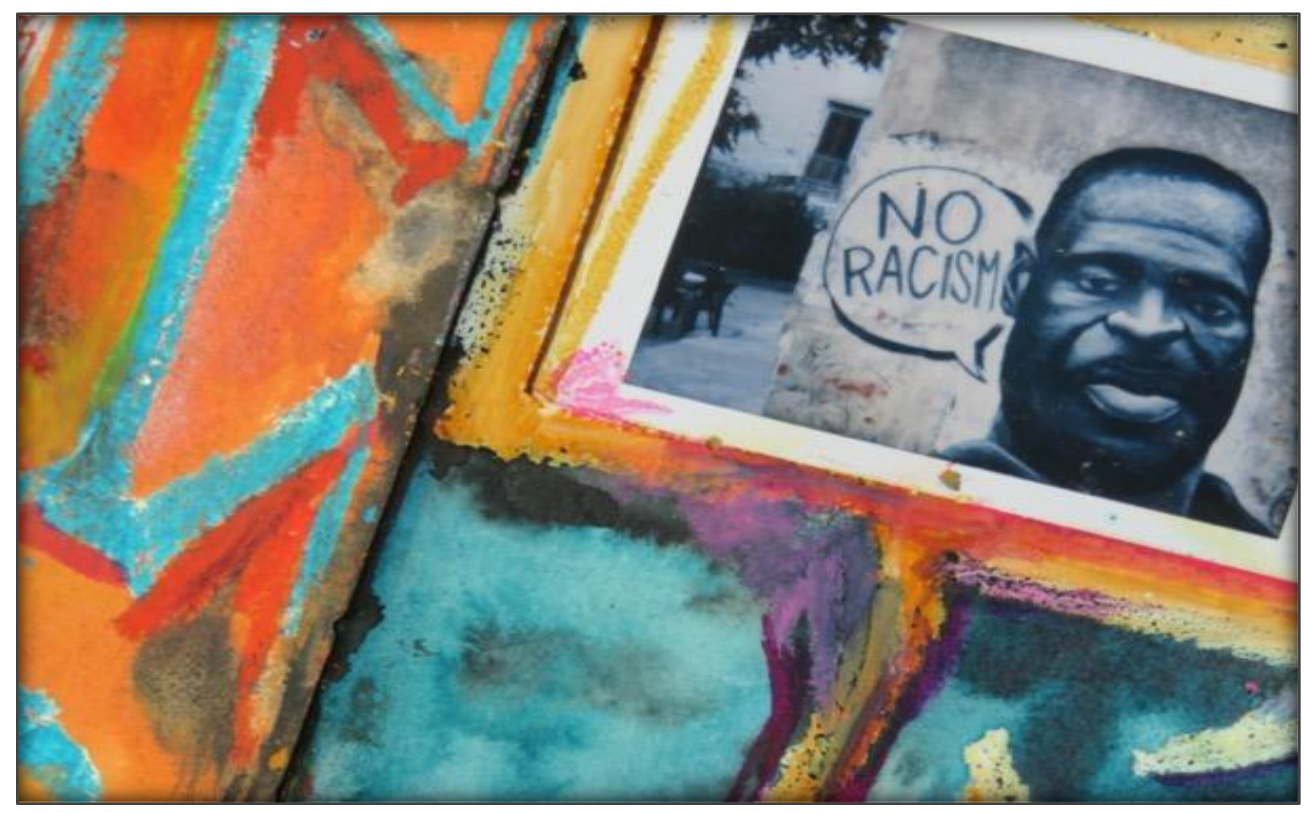

George Floyd in Ballarò. Adriana Oniță, 2020, Polaroid, oil pastel and watercolour on paper.

La mattina del primo giugno, the words "I can't breathe" suddenly appeared, spray-painted on rocks near il mare tirreno by a young Sicilian artist, Mr. Cens. Four days later, as I was walking to Ballarò market, I noticed George Floyd's face on a wall a few meters from my house-exactly 8,214 kilometers from where he was executed. The mural, a collaboration between rapper Christian "Piciotto" Paterniti and street artist Alec, highlights how "il razzismo e il virus più pericoloso" (racism is the most dangerous virus; Gullà, 2020). Later, on an evening walk, I saw a poster of Miss WyntaAmor Rogers from Long Island adorning Palermo's busiest street, Via Maqueda, with the words "feel 
her rage". I wondered how many walkers, tourists or flaneurs would recognize this feisty young activist? How would they feel her rage? I called Lébassé and we marveled at how the walls of the streets speak louder and faster than any school or museum ever could.

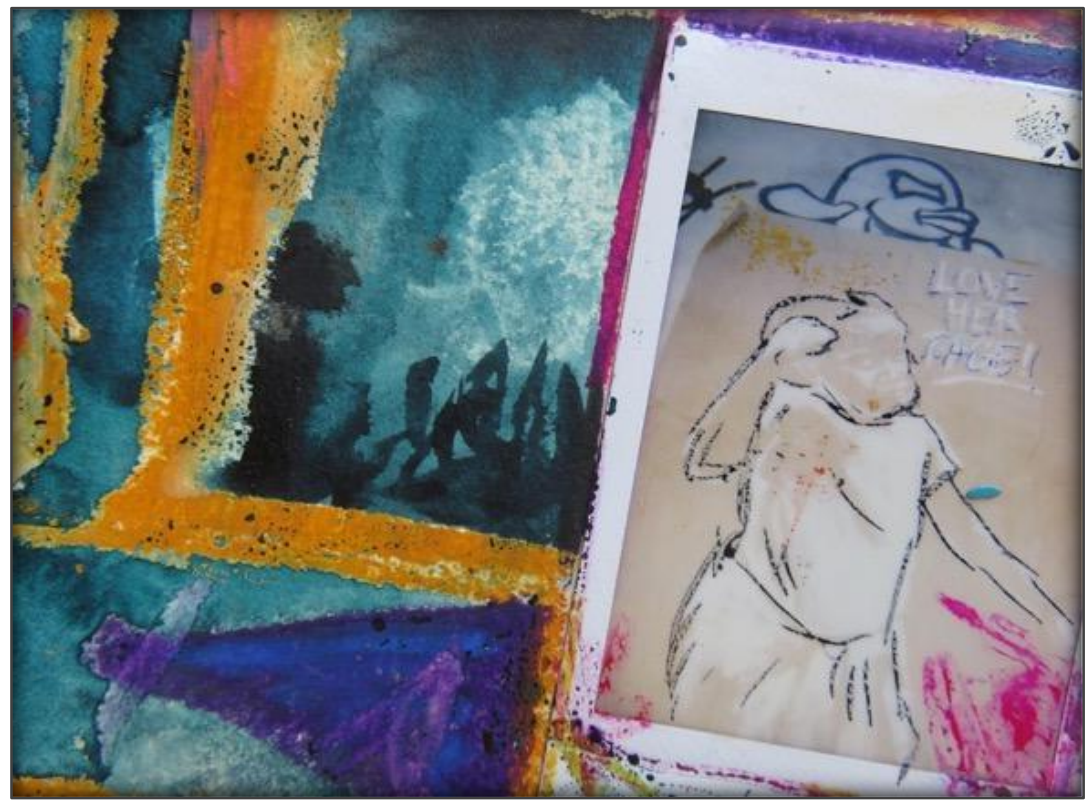

Poster of Wynta-Amor Rogers in Palermo. Adriana Oniță, 2020.

Polaroid, oil pastel and watercolour on paper.

Despite our eight-hour time difference, Lébassé and I talk almost daily on the phone. We speak about the global Black Lives Matter protests, police brutality, rampant racism in Edmonton schools, and the White supremacy sewn into the very fabric of Alberta curricula. After the murders of Ahmaud Arbery, Breonna Taylor and George Floyd, and the protests that ensued, we marveled at social media exploding with outrage (for a week or two). We witnessed painful and paradoxical performative allyship on these platforms, even from close friends.

As Lébassé and I would walk and talk together, so many uncomfortable questions arose for me: what did my Instagram black square accomplish; how has my identity as a non-Indigenous româncă informed my understanding of curriculum and teaching in Canada and beyond; why am I sometimes so "unsettled" when I reflect on the benefits I receive from deeply ingrained systems of White privilege and settler privilege; can true critical self-reflection even occur without discomfort; what is non-optical allyship; how can I embed social, racial and linguistic justice throughout my curricula and teaching, not just as an add-on or an occasional curricular theme? As we walked, we discussed these questions and more, such as: who gets to walk for leisure and creativity; and who feels harassed, followed, or assaulted while they walk because of their race, gender expression, religion, class or abilities? (Kunkle, 2015; Streeter, 2020). 


\section{Curriculum of Bones}

In my walks, I noticed that the walls of my current city raise important questions, curricular questions I had never even thought to ask.

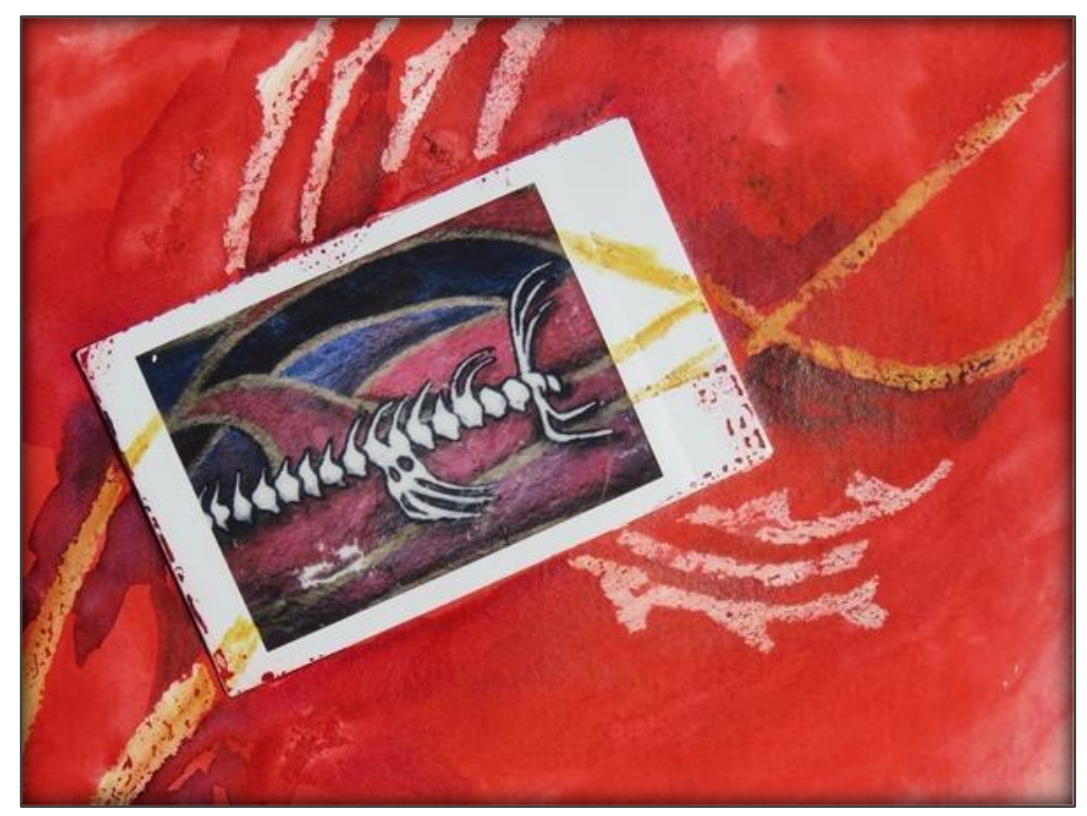

Curriculum of Bones. Adriana Oniță, 2020, Polaroid, oil pastel and watercolour on paper.

How can we do justice to this new curriculum of breath, of bones, of steps, of screens, of protest? In Prendergast's (2020) found poems of Carl Leggo's prose, one line moved me to tears: "I walk the course of loss / this curriculum of loss" (p. 18). I dwelled with this line on my walks as I navigated my own grief and despair at the loss of this year. But I also tried to hang on to Carl Leggo's "curriculum of hope", as the walls continued to attune me to urgent world issues, guiding my art and conversations with Lébassé and Lucie. In one August passeggiata, I photographed street art that said "non esistono clandestini, ma solo fratelli" (there are no illegals, only brothers) and "aprite $i$ portl' (open the gates), in reference to the current migrant crisis and overwhelming loss of life in the Mediterranean, especially near Sicily. This reminded me of a common 2020 slogan regarding COVID19: "We're all in the same boat". After my walk, I created a counter-response and shared it with my co-authors and students. 


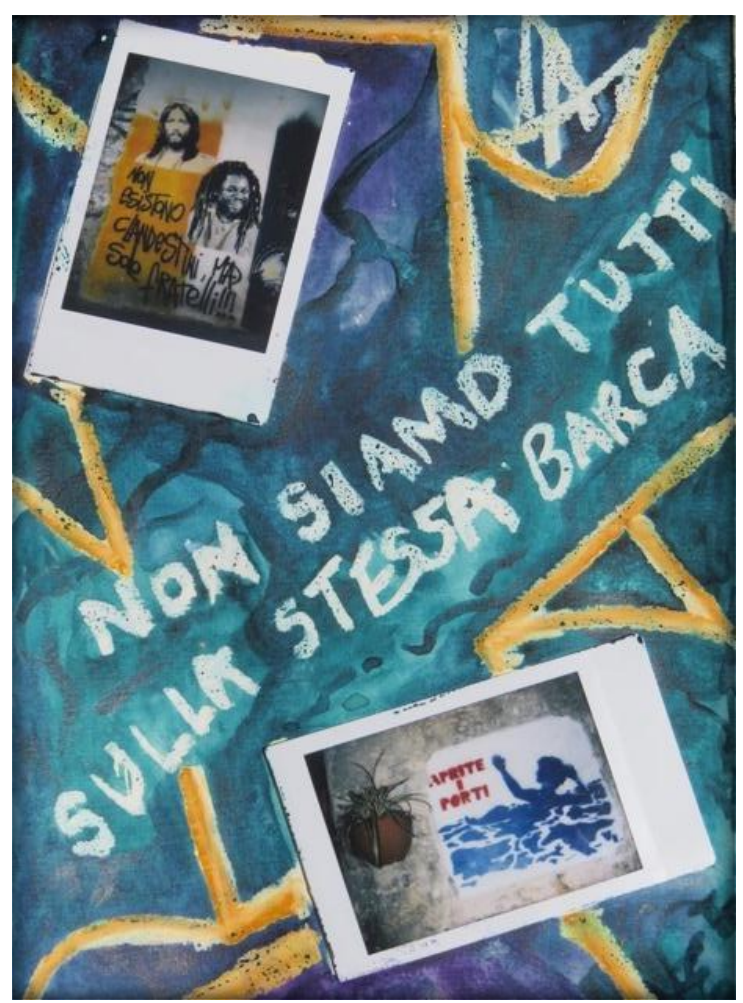

We're Not All in the Same Boat. Adriana Oniță, 2020. Pastel, watercolour and polaroid photo on paper.

The multisensorial act of plimbari in Palermo led to deeper attunement to my surroundings, as well as to world issues at the intersections of racism, COVID-19, walking and teaching. Using the insights from this project, I designed, in August 2020, a month-long Spanish Art Camp for youth aged 13-17, to work in resistance to the Anglocentric mono-lingualizing ideology of society, schools and curricula, in Canada. I was inspired by Nieto's (2013) Culturally Responsive Teaching, and Cummins's (2009) Transformative Multiliteracies Pedagogy, both intended to honour students' heritage languages through curricula that builds upon their cultural and linguistic capital, and values, and which affirms their identities, and empowers them to create literature and art about their social realities (Cummins, 2009).

In order to put these ideas into practice, I researched and included artists from the youths' cultures into the camp curriculum, centred self-expression and experiences in their heritage language, and made space for uncomfortable emotions, as well as dialogue and inquiry into world issues they deeply cared about, such as racism, linguistic discrimination, environmental destruction, LGBTQIA + issues and mental health. A focus on Protest Art, which was afterwards described by many of the participants as a favourite part of the camp, shows how impactful arts-based language learning can be when married with anti-racist education. 


\section{Ce am învătat: Ce qu'on a appris}

We began this ten-week arts-based research project at the height of a pandemic and a racial revolution. Not knowing where our artistic processes would lead, întrebarea noastra era: how might walking and art-making help us reflect, inquire, create, and act upon, new understandings of antiracist education? Through our project, we were able to feel what Feinberg (2016) meant by curriculum as "lived and emerging, somatic and contextual, personal yet political, and enhanced by curiosity and listening" (p. 150). Making space for difficult and uncomfortable emotions, bodily sensations and self-expression, through art and through our writing in heritage languages, allowed for dehabituation and growth for both ourselves and our students. Thus, our arts-based research process helps build upon Frimberger's (2016) walking-based pedagogy and Judson's (2018) walking curriculum to include active anti-racist work through art-making and language learning and teaching. By listening - to our surroundings, to our bodies, and to each other-nos dimos cuenta that there is no clear-cut path to follow in the fight for anti-racism and each path is truly unique. Whether we walked in nature, in the city, or in IKEA, we demonstrated the truth of poet Antonio Machado's words: "caminante no hay camino. / se hace camino al andar." (walker, there is no path: the path is made by walking; poem XXIX of the collection "Proverbios y Cantares"; see Machado, 1989; see also http://www.rinconcastellano.com/biblio/sigloxx_98/amachado_prov.html or http://www.armandfbaker.com/poems.html).

\section{About the Authors}

Adriana Oniță is a poet, artist, educator and $\mathrm{PhD}$ candidate at the University of Alberta exploring Heritage Language Maintenance through the arts. Născută în București, she has lived and taught in amiskwaciwâskahikan/Edmonton, Granada, Bologna and Palermo. Adriana is also the founding editor of The Polyglot, a magazine that has published over 150 multilingual poets and artists working in over 40 languages (www.thepolyglotmagazine.com).

Lébassé Guéladé-Yaï is a daughter, a sister and a friend. She has always been drawn to people: the stories they share, the lives they live. With social justice in her heart, her truth lies in the wellbeing of the people that surround her, her community and her world. Her name means being home without being from here, it's the beginning of a story her parents built and that she quickly made her own as a first generation Black Canadian.

Lucie Wallace is a trilingual French-Canadian educator from Edmonton, Alberta. In the past ten years, the conversion of language and art education has been her main focus. It is a constant sense of curiosity that has inspired her to engage in teaching and learning in traditional classroom settings as well as in museums and other cultural spaces in Canada, France, Spain and China. Lucie is currently teaching and coordinating the Primary Years French language Programme at Mulgrave School, the International School of Vancouver where she is most curious about utilizing language learning as a force for change. 


\section{References}

Beier, J. L. (2014). Schizophrenizing the art encounter: Towards a politics of dehabituation. [Master's thesis]. University of Alberta. https://era.library.ualberta.ca/items/24a514f8-b85e-4d18-93b90cd9d83e03d2/view/dde5cfec-cca7-46e8-95ac-f89fd03d7661/beier_jessie_I_201409 _masters.pdf

Conrad, D., \& Beck, J. (2015). Towards articulating an arts-based research paradigm: Growing deeper. UNESCO Observatory Multidisciplinary Journal in the Arts, 5(1), 1-26. https://www.unescoe journal.com/wp-content/uploads/2020/04/5-1-5-CONRAD.pdf

Cummins, J. (2009). Pedagogies of choice: Challenging coercive relations of power in classrooms and communities. International Journal of Bilingual Education and Bilingualism, 12(3), 261-271. https://doi-org.ezproxy.lakeheadu.ca/10.1080/13670050903003751

Dei, G. J. S. (1995). Examining the case for "African-centred" schools in Ontario. McGill Journal of Education, 30(2), 179-198. https://mje.mcgill.ca/article/view/8239/6167

Feinberg, P. P. (2016). Towards a walking-based pedagogy. Journal of the Canadian Association for Curriculum Studies, 14(1), 147-165. https://jcacs.journals.yorku.ca/index.php/jcacs /article/download/40312/36186

Figliuzzi, A. (2020, August 23). Relational pedagogy: A different approach for our new reality. Studio Art Sessions. https://www.studioartsessions.ca/post/relational-pedagogy-a-differentapproach-for-our-new-reality

Gullà, M. (2020, June 5). A Ballarò un murale con il volto di George Floyd: Il razzismo e il virus più pericoloso [In Ballarò, a mural with the face of George Floyd: Racism is the most dangerous virus]. Palermo Giornale di Sicilia. https://palermo.gds.it/video/cultura/2020/06/05/a-ballaroun-murale-con-il-volto-di-george-floyd-il-razzismo-e-il-virus-piu-pericoloso-5a89fd17-f6844bc8-8c54-06341354f939/

Judson, G. (2018). A walking curriculum: Evoking wonder and developing sense of place. imaginED.

Knowles, J. G., \& Cole, A. L. (Eds.). (2008). Handbook of the arts in qualitative research: Perspectives, methodologies, examples, and issues. Sage.

Kunkle, F. (2015, Oct 26). 'Walking while black' can be dangerous too, study finds. Washington Post. https://www.washingtonpost.com/news/dr-gridlock/wp/2015/10/26/walking-while-black-canbe-deadly-too-study-finds/

Machado, A. (1989). XXIX. In O. Macrí \& G. Chiappini (Eds.), Obras Completas, t. I, Poesías Completas, t. II, Prosas Completas [Complete Works, Vol. 1, Complete Poems, Vol. 2, Complete Prose, Vol. 3]. Espasa-Calpe.

Nieto, S. (2013). Finding joy in teaching students of diverse backgrounds: Culturally responsive and socially just practices in U.S. classrooms. Heinemann.

Prendergast, M. (2020). Dwelling in the human/posthuman entanglement of poetic inquiry: Poetic missives to and from Carl Leggo. Journal of the Canadian Association for Curriculum Studies, 17(2), 13-33. https://jcacs.journals.yorku.ca/index.php/jcacs/article/view/40442/36455 
Rev Transcript Library. (2020). Justin Trudeau Canada COVID-19 Press Conference Transcript May 22. https://www.rev.com/blog/transcripts/justin-trudeau-canada-covid-19-press-conferencetranscript-may-22

Streeter, K. (2020, May 18). Running while black: Our readers respond. The New York Times. https://www.nytimes.com/2020/05/18/sports/running-while-black-ahmaud-arbery.html

Verissimo, J. (2019, August 28). On the politics of italics. Literary Hub. https://lithub.com/on-thepolitics-of-italics/ 